\title{
The Profile Analysis of Problem-Solving Skills on Work and Energy Material Using "Multiple-Ways of Rosengrant"
}

\author{
V Vidyawati ${ }^{1}$, P Sinaga $^{2}$, L Hasanah $^{3}$ \\ \{vidyawati@upi.edu ${ }^{1}$ \}

\begin{abstract}
Departemen Pendidikan Fisika, Universitas Pendidikan Indonesia, Indonesia ${ }^{1,3}$
Departemen Pendidikan Ilmu Pengetahuan Alam, Universitas Pendidikan Indonesia, Indonesia ${ }^{2}$
\end{abstract}

\begin{abstract}
This research aims to determine the improvement of problem-solving skills and skill level in solving problems on the business and energy topic of high school students. The research method used is the quasi-experiment with a post-test control group pre-test design. The subject for this study amounted to 60 SMA grade $X$ students at one of the schools in Bandung which was determined by purposive sampling. The instrument used is a matter of essay based on problems in everyday life. Measurement of problem-solving capability is a pre-test and post-test corresponding to the Multiple-ways of the Rosengrant indicator. Data analysis uses the percentage of average gain in normalization and interacting with hake criteria. After the study, there was an increase in problem-solving skills with moderate criteria, with an $\langle\mathrm{g}\rangle \mathrm{N}$-gain normalization rate of 0.49 . The results showed improved problem-solving skills at each level.
\end{abstract}

Keywords: Problem Solving Skills, Quasi-Experiment, Multiple-Ways of Rosengrant

\section{Introduction}

Physics is a part of natural science and is developed based on physical phenomena that happen in nature from a series of the scientific process. Many students already have a good understanding of physics' concepts and principles, but the ability to solve physics problems is still lacking [1]. Because of that, an effective learning strategy is still needed to be done by teachers [2]. One way to solve the physics problem is students must deeply understand the physics concepts. Students are also required to master various representations simultaneously.

Learning by using various forms of representation can facilitate students to explore more about physics concepts [3]. Using appropriate forms of representation about physics concepts that are taught will make students not only memorize it but also understand the concept as well [4]. To be able to learn physics effectively, students must understand the use of representations in explaining a physical concept and manage to translate representations of a concept from one form to another [5]. With the representation format, questions and concepts can be expressed in various ways, such as by using graphics, free body diagrams, and others. Having skills in using various representations and coordinating multi representations is very beneficial in learning physics, other than as a tool to understand concepts. Those skills even can facilitate students' problem-solving skills [6]. Based on the literature's study, research on multi-representation with the ability of student representation in solving problems has been done by Rosengrant, et. all, 2007b[7]. The research is focusing on the ability of students to solve problems using 
representations, the emergence of representations, and the quality of representations. The intended representation is free-body diagrams. The result of the study shows that free-body diagrams are beneficial if students make the free-body diagrams correctly. If students misuse the free body diagrams, they get a low score [7]. Kohl and Finkelstein concluded that student's success in solving physical problems was influenced by the format of representation of those physics problems [7],[ 8].

This article aims to gain an overview of learning strategies to improve student's problemsolving skills and to escalate student's ability to build a representation of physics problems in work and energy material. The model of system representation from Triadic Peirce is shown on Figure 1.

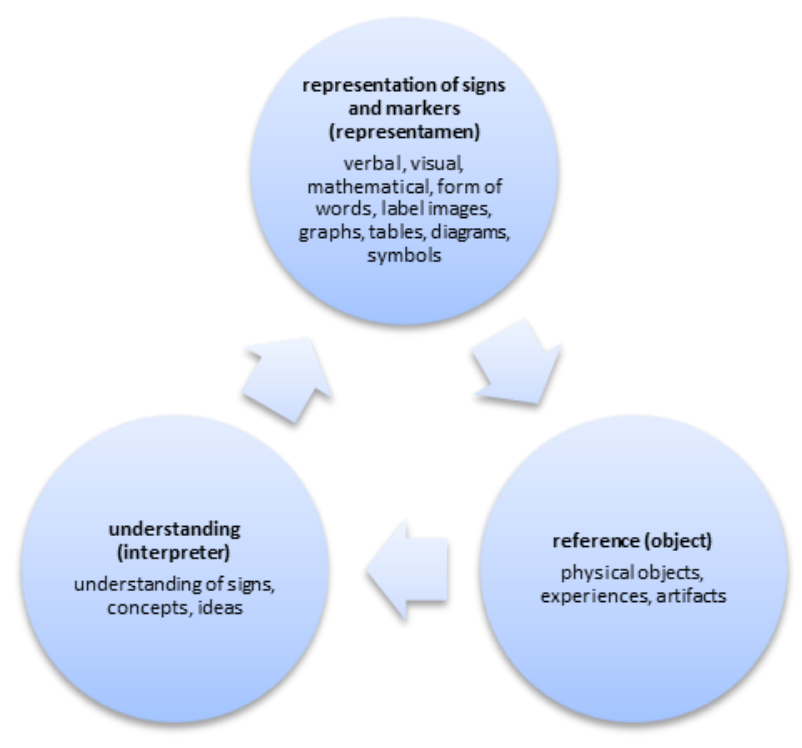

Fig. 1. The model of system representation from Triadic Peirce [9].

\section{Experimental Method}

The method used in this study was quasi-experiment by comparing the experimental class and the control class results[10]. The experimental class is a class of students who learn with the Rosengrant multi representation-based problem-solving strategy, while the control class learns with the Polya problem-solving strategy. Pre-test and post-test are done to both classes to see the development of students' problem-solving skills and the ability to build a representation. Based on the research purpose conducted, the research design used is the pretestposttest of non-equivalent group design [11]. In this design, the study uses experimental groups and comparative groups that begin with an initial test (pre-test) given to both groups. After that, treatment is given to both groups. The research ends with a post-test given to both groups. The population in this study is all 10th-grade MIPA students in one of the Senior High School in West Bandung district in 2018/2019 school year. While the samples involved in this research are two classes of X MIPA which includes 60 students. 
The sampling technique used is purposive sampling. Sample from the population conducted by considering the classes that received work and energy material in the high school's curriculum.

Problem-solving skill is measured by using the essay test as the instrument. The test is done to know students' success rate in learning on their problem-solving skills and building representation ability. The levels of problem-solving skills are determined by creating an assessment rubric adapted from Rossengrant. The levels consist of: Missing (very low/zero), Inadequate (less capable/low), Needs Some Improvement (need development/moderate) and Adequate (capable/good). Based on those levels or classification, students' problem-solving skills can be measured and classified.

Students' ability to build a free body diagram (FBD) representation is measured by using an essay test as the instrument. The levels of building free body diagram skill, show on Table 1. This test is done to know students' ability in analyzing and describing the free body diagrams of an object. Students' ability to draw free body diagrams is classified by using free-body diagrams skills rubric [7]. The rubric consists of four levels. Each level has the characteristics from the lowest level to the highest level. Multi-representation skill's assessment rubric show on Table 2

Table 1. The levels of building free body diagram skill.

\begin{tabular}{|c|c|c|c|}
\hline No evidence of & Inadequate & Needs improvement & Adequate \\
\hline 0 & 1 & 2 & 3 \\
\hline $\begin{array}{l}\text { No representation } \\
\text { is depicted. }\end{array}$ & $\begin{array}{l}\text { There is FBD } \\
\text { depicted, but there are } \\
\text { still some errors such } \\
\text { as the existence of } \\
\text { additional styles that } \\
\text { are not included in the } \\
\text { object system and the } \\
\text { wrong vector } \\
\text { directions of the } \\
\text { force. }\end{array}$ & $\begin{array}{l}\text { There is FBD depicted } \\
\text { and no additional style } \\
\text { includes in the object } \\
\text { system. But there is an } \\
\text { error in labelling the } \\
\text { name of the force and } \\
\text { the vector length from } \\
\text { the force. }\end{array}$ & $\begin{array}{l}\text { The depicted FBD is } \\
\text { complete. There is no } \\
\text { fault in labelling } \\
\text { force's names, vector } \\
\text { depictions, and force } \\
\text { direction. By that, the } \\
\text { depicted FBD } \\
\text { matches the presented } \\
\text { problem. }\end{array}$ \\
\hline
\end{tabular}

Table 2. Multi-representation skill's assessment rubric.

\begin{tabular}{|c|c|c|c|c|c|}
\hline $\begin{array}{l}\text { No } \\
\text {. }\end{array}$ & $\begin{array}{l}\text { Scientific } \\
\text { skills }\end{array}$ & $\begin{array}{l}\text { Missing } \\
\text { [score 0] }\end{array}$ & $\begin{array}{l}\text { Inadequate } \\
\text { [score 1] }\end{array}$ & $\begin{array}{l}\text { Needs Some } \\
\text { Improvement } \\
\text { [score 2] }\end{array}$ & $\begin{array}{c}\text { Adequate } \\
\text { [score 3] }\end{array}$ \\
\hline 1 & $\begin{array}{l}\text { Able to } \\
\text { properly } \\
\text { filter } \\
\text { information } \\
\text { from a } \\
\text { representati } \\
\text { on. }\end{array}$ & $\begin{array}{l}\text { No effort was } \\
\text { made to sift } \\
\text { through the } \\
\text { information } \\
\text { from the } \\
\text { presented } \\
\text { problem. }\end{array}$ & $\begin{array}{l}\text { There are errors } \\
\text { in filtering } \\
\text { information, } \\
\text { such as less } \\
\text { precise in } \\
\text { labeling } \\
\text { amounts. }\end{array}$ & $\begin{array}{l}\text { Some information } \\
\text { is filtered } \\
\text { correctly, but only } \\
\text { partially. The } \\
\text { numbers are only } \\
\text { filtered with } \\
\text { proper labeling } \\
\text { but without a unit. }\end{array}$ & $\begin{array}{l}\text { All important } \\
\text { information is } \\
\text { filtered } \\
\text { appropriately } \\
\text { and formed } \\
\text { representation } \\
\text { is visible. }\end{array}$ \\
\hline
\end{tabular}




\begin{tabular}{|c|c|c|c|c|c|}
\hline $\begin{array}{l}\text { No } \\
\text {. }\end{array}$ & $\begin{array}{l}\text { Scientific } \\
\text { skills }\end{array}$ & $\begin{array}{l}\text { Missing } \\
\text { [score 0] }\end{array}$ & $\begin{array}{l}\text { Inadequate } \\
\text { [score 1] }\end{array}$ & $\begin{array}{l}\text { Needs Some } \\
\text { Improvement } \\
\text { [score 2] }\end{array}$ & $\begin{array}{l}\text { Adequate } \\
\text { [score 3] }\end{array}$ \\
\hline 2. & $\begin{array}{l}\text { Able to } \\
\text { make } \\
\text { representati } \\
\text { ons from } \\
\text { previous } \\
\text { representati } \\
\text { ons. }\end{array}$ & $\begin{array}{l}\text { No effort was } \\
\text { made to make } \\
\text { a different } \\
\text { representation }\end{array}$ & $\begin{array}{l}\text { There are } \\
\text { attempts to } \\
\text { make } \\
\text { representations. } \\
\text { But students } \\
\text { still use } \\
\text { incorrect } \\
\text { information or } \\
\text { inappropriate } \\
\text { representations. }\end{array}$ & $\begin{array}{l}\text { Representations } \\
\text { are made without } \\
\text { error, but no } \\
\text { information such } \\
\text { as naming and } \\
\text { variables. }\end{array}$ & $\begin{array}{l}\text { Representation } \\
\mathrm{s} \text { are made } \\
\text { using all } \\
\text { information } \\
\text { and do not } \\
\text { contain large } \\
\text { flaws. }\end{array}$ \\
\hline 3 & $\begin{array}{l}\text { Able to } \\
\text { assess the } \\
\text { consistency } \\
\text { of different } \\
\text { representati } \\
\text { ons and } \\
\text { modify } \\
\text { them if } \\
\text { needed. }\end{array}$ & $\begin{array}{l}\text { No } \\
\text { representation } \\
\text { is made to } \\
\text { assess the } \\
\text { suitability. }\end{array}$ & $\begin{array}{l}\text { One } \\
\text { representation is } \\
\text { made but there } \\
\text { is no suitability } \\
\text { between the } \\
\text { representations } \\
\text { made with the } \\
\text { representation } \\
\text { provided. }\end{array}$ & $\begin{array}{l}\text { Representations } \\
\text { are made } \\
\text { according to each } \\
\text { other but there is a } \\
\text { slight discrepancy } \\
\text { in the } \\
\text { representation } \\
\text { given. It can be a } \\
\text { modification } \\
\text { made in the } \\
\text { representation. }\end{array}$ & $\begin{array}{l}\text { All } \\
\text { representations } \\
\text {, both made } \\
\text { and given, } \\
\text { have } \\
\text { compliance } \\
\text { with each } \\
\text { other. }\end{array}$ \\
\hline 4. & $\begin{array}{l}\text { Able to use } \\
\text { representati } \\
\text { ons to solve } \\
\text { problems. }\end{array}$ & $\begin{array}{l}\text { No effort was } \\
\text { made to } \\
\text { answer the } \\
\text { questions. }\end{array}$ & $\begin{array}{l}\text { Giving wrong } \\
\text { answers. }\end{array}$ & $\begin{array}{l}\text { The answer is } \\
\text { correct but } \\
\text { representation is } \\
\text { not used. }\end{array}$ & $\begin{array}{l}\text { The answer is } \\
\text { correct and } \\
\text { multi } \\
\text { representation } \\
\text { is used. There } \\
\text { are also some } \\
\text { mathematical } \\
\text { calculations. }\end{array}$ \\
\hline \multicolumn{6}{|c|}{ Assessment rubric based on the representation that can be created by students } \\
\hline 5. & $\begin{array}{l}\text { Free-Body } \\
\text { Diagram } \\
\text { (FBD) }\end{array}$ & $\begin{array}{l}\text { No } \\
\text { representation } \\
\text { made. }\end{array}$ & $\begin{array}{l}\text { FBD has been } \\
\text { created, but } \\
\text { there are still } \\
\text { errors such as } \\
\text { mislabelled or } \\
\text { no labelling on } \\
\text { force's vector. } \\
\text { Vector length } \\
\text { and vector } \\
\text { direction are still } \\
\text { wrong. }\end{array}$ & $\begin{array}{l}\text { There is no fault } \\
\text { on created FBD. } \\
\text { But it is still a lack } \\
\text { of label } \\
\text { completeness on } \\
\text { force's vector or } \\
\text { vectors not drawn } \\
\text { from a single } \\
\text { point (position of } \\
\text { objects are on the } \\
\text { system). }\end{array}$ & $\begin{array}{l}\text { There is no } \\
\text { fault on created } \\
\text { FBD and every } \\
\text { force is } \\
\text { labeled. So, it } \\
\text { is easy to } \\
\text { understand the } \\
\text { forces that } \\
\text { have been } \\
\text { shown. }\end{array}$ \\
\hline 7. & $\begin{array}{l}\text { Energy } \\
\text { Flow } \\
\text { Diagrams }\end{array}$ & $\begin{array}{l}\text { No } \\
\text { representation } \\
\text { made. }\end{array}$ & $\begin{array}{l}\text { The diagram } \\
\text { that is made } \\
\text { does not indicate } \\
\text { flow/movement, } \\
\text { The fault can be } \\
\text { the vector } \\
\text { motion is not } \\
\text { created, and the }\end{array}$ & $\begin{array}{l}\text { No error in } \\
\text { creating motion } \\
\text { vector diagrams, } \\
\text { but there is still a } \\
\text { deficiency in the } \\
\text { form of a single } \\
\text { point } \\
\text { representing the } \\
\text { position of the }\end{array}$ & $\begin{array}{l}\text { The overall } \\
\text { diagram is } \\
\text { correct and } \\
\text { clear. } \\
\text { Description of } \\
\text { the motion of } \\
\text { an object on } \\
\text { the path is } \\
\text { made. }\end{array}$ \\
\hline
\end{tabular}




\begin{tabular}{|c|c|c|c|c|c|}
\hline $\begin{array}{l}\text { No } \\
\text {. }\end{array}$ & $\begin{array}{l}\text { Scientific } \\
\text { skills }\end{array}$ & $\begin{array}{l}\text { Missing } \\
\text { [score 0] }\end{array}$ & $\begin{array}{l}\text { Inadequate } \\
\text { [score 1] }\end{array}$ & $\begin{array}{l}\text { Needs Some } \\
\text { Improvement } \\
\text { [score 2] }\end{array}$ & $\begin{array}{l}\text { Adequate } \\
\text { [score 3] }\end{array}$ \\
\hline & & & $\begin{array}{l}\text { less precise of } \\
\text { vector label. }\end{array}$ & $\begin{array}{l}\text { object being or } \\
\text { the difference in } \\
\text { length of the } \\
\text { vector when } \\
\text { experiencing } \\
\text { changes. }\end{array}$ & \\
\hline 8. & Chart & $\begin{array}{l}\text { No } \\
\text { representation } \\
\text { made. }\end{array}$ & $\begin{array}{l}\text { No value from a } \\
\text { single graph is } \\
\text { created, or a } \\
\text { value created in } \\
\text { wrong. The } \\
\text { graph value } \\
\text { interval } \\
\text { representing on } \\
\text { each axis is not } \\
\text { continuous. }\end{array}$ & $\begin{array}{l}\text { The created line } \\
\text { graph } \\
\text { corresponds to the } \\
\text { conservation of } \\
\text { values on the axis } \\
\text { of the chart. But } \\
\text { the formed } \\
\text { graphics are less } \\
\text { precise/not } \\
\text { smooth. }\end{array}$ & $\begin{array}{l}\text { The entire } \\
\text { chart created } \\
\text { between the } \\
\text { two axes is } \\
\text { correct and } \\
\text { corresponds } \\
\text { with the } \\
\text { magnitude of } \\
\text { the } \\
\text { conservation } \\
\text { of the value } \\
\text { interval. }\end{array}$ \\
\hline 9. & Pictures & $\begin{array}{l}\text { No } \\
\text { representation } \\
\text { is made. }\end{array}$ & $\begin{array}{l}\text { Images are } \\
\text { created, but not } \\
\text { exhaustive } \\
\text { because there is } \\
\text { a deficiency in } \\
\text { the physical } \\
\text { label or } \\
\text { misinformation. }\end{array}$ & $\begin{array}{l}\text { The images of the } \\
\text { majority of items } \\
\text { are created, but } \\
\text { there is still less } \\
\text { precise label } \\
\text { information on } \\
\text { the image item. }\end{array}$ & $\begin{array}{l}\text { The whole } \\
\text { image contains } \\
\text { all the correct } \\
\text { and precise } \\
\text { items. }\end{array}$ \\
\hline 10. & $\begin{array}{l}\text { Mathematic } \\
\text { al }\end{array}$ & $\begin{array}{l}\text { No } \\
\text { representation } \\
\text { is made. }\end{array}$ & $\begin{array}{l}\text { Mathematical } \\
\text { representations } \\
\text { that do not have } \\
\text { algebraic } \\
\text { passages } \\
\text { (directly include } \\
\text { numbers), } \\
\text { applying the } \\
\text { wrong concept } \\
\text { of algebraic. }\end{array}$ & $\begin{array}{l}\text { There are no } \\
\text { errors found in } \\
\text { analysing, but the } \\
\text { description of the } \\
\text { problem solving } \\
\text { is less complete. } \\
\text { There is still a } \\
\text { unit of algebra } \\
\text { that is made less } \\
\text { or less precise. }\end{array}$ & $\begin{array}{l}\text { There is no } \\
\text { fault in } \\
\text { mathematical } \\
\text { representation. } \\
\text { It is written } \\
\text { systematically. }\end{array}$ \\
\hline
\end{tabular}

\section{Result and Discussion}

Based on data findings and analysis, Rosengrant's problem-solving strategy can improve student's problem-solving skills with a normalized gain of 0.49 in the medium category. While the Polya problem-solving strategy can improve student problem-solving skills with a normalized gain of 0.15 in the low category. The comparison can be seen on Figure 2. 


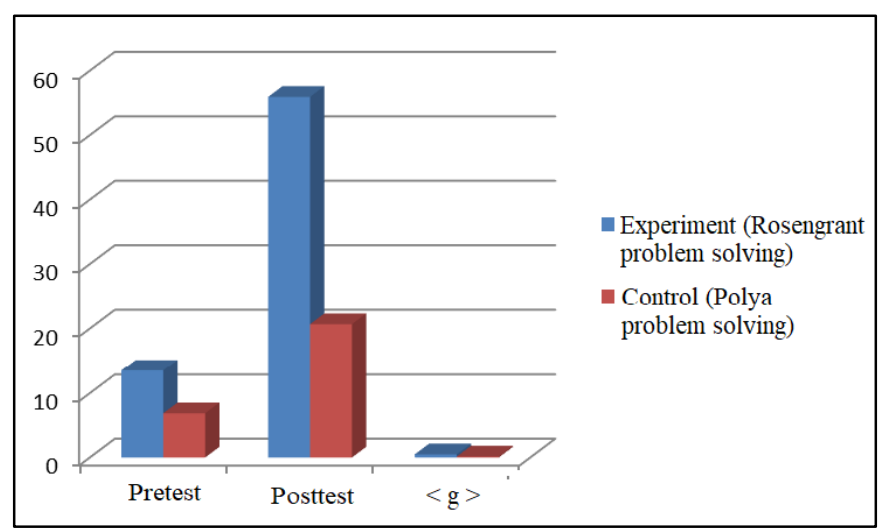

Fig. 2. The comparison of Rosengrant's problem-solving skill gain with Polya problem-solving skill gain.

Based on the Rosengrant framework of problem-solving skills, there are four stages of problem-solving capabilities: the ability to translate problems, simplify problems, depict free body diagrams, and write mathematical equations and its solutions. For each stage of ability, the accomplishment is analyzed based on the acquisition of pretest, posttest and N-gain scores. Based on the data, it is known that all the problem-solving stages are improving in both the Rosengrant problem-solving strategy class and the Polya problem-solving class. The result can be seen on Figure 3.

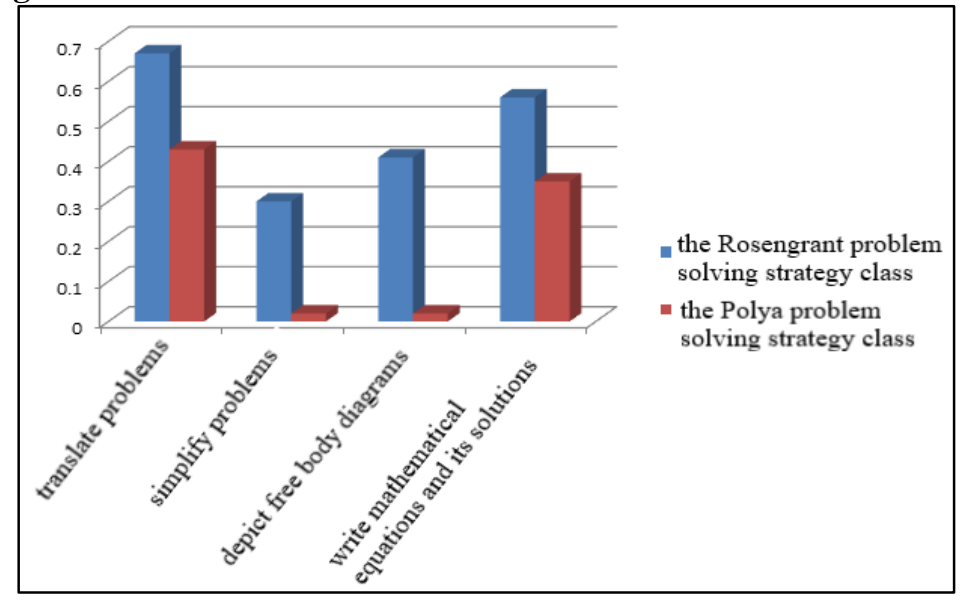

Fig. 3. The result of students' collaboration skill.

Students' ability to build physics representations is categorized by Multi-representation skill's assessment rubric by Rosengrant. The ability is measured in the form of percentages based on the number of students at each level. In the problem-solving strategy of Rosengrant class, the highest average percentage was at level 3 of $67.5 \%$, next is Level 2 of $25.8 \%$, Level 4 by $4.17 \%$ and level 1 by $2.5 \%$. In the problem-solving strategy of Polya class, the highest average percentage of the ability to build physics representation is at $47.5 \%$, next is Level 2 by $31.7 \%$, at level 3 by $19.2 \%$ and at level 4 by 1.7\%. The comparison can be seen on Figure 4 . 


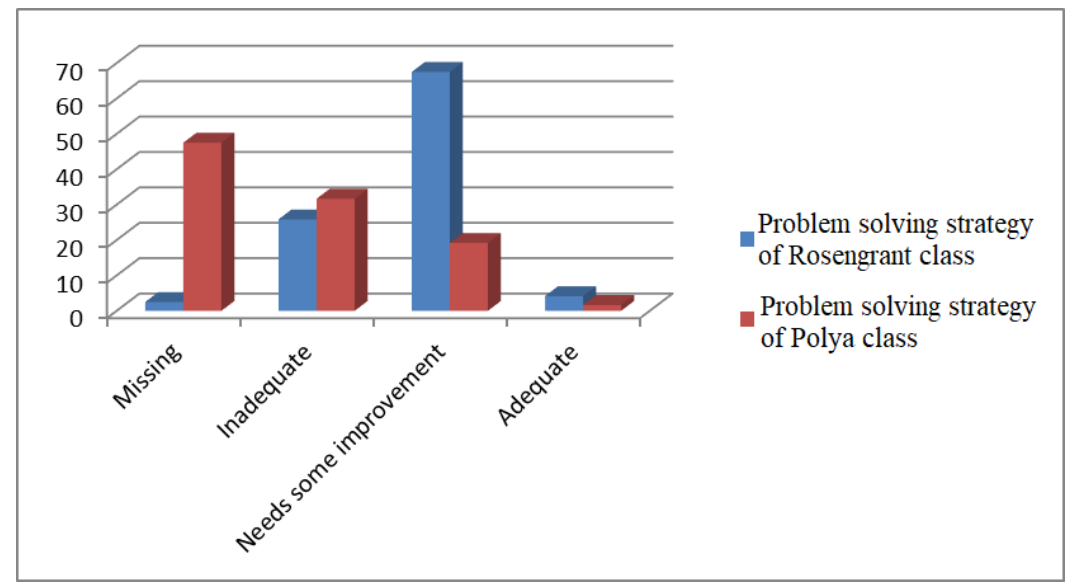

Fig. 4. Students' ability to build physics representation at each level in the problem-solving strategy of Rosengrant class and problem-solving strategy of Polya class.

Based on the analysis of both classes, the number of students' percentage at each level shows that students in problem-solving strategy with Rosengrant's multi representation approach class is better on building more complex representation than students in the problemsolving strategy with Polya class.

This happens because students from the experimentation class get to study problem-solving strategies with a multi representational approach that provides the ability to build representation. At the learning activity, students are given the appearance of pictures, videos, and demonstrations as a means of familiarizing students with identifying the key concept. After students have obtained the key concept, students are subsequently trained to create a new representation of the displayed image along with the verb instructions to create an image of physics. One of them is in the form of a free body diagram. So, the overview of internal representation is obtained which then becomes the resulting external representation. While in the class of problem-solving strategies with Polya, students do not acquire activities that practice the ability to build such representations.

\section{Conclusion}

Rosengrant's problem-solving learning strategy involves the active role of students in learning activities on describing the representations acquired and solve problems. So that they can be used in learning other materials. Implementing The Rosengrant problem-solving strategy needs to be applied by teachers consistently so that students are better trained in solving physical problems.

Acknowledgments. Researchers would like to thank all parties who have assisted in the implementation of this research, especially the high school party in West Bandung regency that has allowed researchers to do research there. 


\section{References}

[1] Cruz, Thelma Ds.: The Effect of Structured Problem Solving Strategy on Performance in Physics among Students Who are Enrolled in the University of Rizal System. International Journal of Scientific and Research (2014)

[2] Docktor, J.L., \& Mestre, J.P.: Synthesis of discipline-based education research in physics. Physical Review Special Topics - Physics Education Research, 10 (2), pp. 15549178 (2014)

[3] Suhandi, A., \& Wibowo, F. C.: Pendekatan Multirepresentasi dalam Pembelajaran Usaha-Energi dan Dampak terhadap Pemahaman Konsep Mahasiswa. Jurnal Pendidikan Fisika Indonesia, (8): pp. 17 (2012)

[4] Arum, I. D. M., Abdurrahman, \& Nyeneng, I. D. P.: Pengaruh Kemampuan Representasi Visual terhadap Hasil Belajar Fisika. Lampung: UNILA (2014)

[5] Ainsworth S, Labeke V.N, \& Peevers G.: Learning with Multiple Representations.(online). Diakses dari alamat (http://www.psychology) (2001)

[6] Cock, M. D.: Representation Use and Strategy Choice in Physics Problem Solving. Phys. Rev. ST Phys. Educ. Res, (8): pp. 1-15 (2012)

[7] Rosengrant, D., Van Heuvelen, A., \& Etkina, E.: Do Students Use and Understand Free Body Diagrams?. Physical Review, Special Topics, Physics Education Research, 5, 010108. (Online) (2009)

[8] Kohl, P. B., Rosengrant, D., \& Finklestein, N. D.: Strongly and Weakly Directed Approach to Teaching Multiple Representation Use in Physics. Physics Education Research, (3), pp. 010108 (2007) [9] Ainsworth, S.: The Function of Multiple Representations. Computers and Education, 33. 131-152 (1999)

[10] M. Aminah, Y. S. Kusumah, D. Suryadi, and U. Sumarmo, "The Effect of Metacognitive Teaching and Mathematical Prior Knowledge on Mathematical Logical Thinking Ability and Self-Regulated Learning," Int. J. Instr., vol. 11, no. 3, pp. 45-62 (2018)

[11] Frankel, J. R., Wallen, N. E. Hyun dan Hellen, H.: How to design and Evaluate Research in Education. New York: McGraw-Hill (2012) 